\title{
Mckenzie Excercise dalam Penurunan Disabilitas Pasien Non- Specific Low Back Pain
}

\author{
Ganesa Puput Dinda Kurniawan \\ Politeknik Kesehatan Jakarta III \\ email: ganesakurniawan@gmail.com
}

Submitted: 26-04-2019, Revised: 20-05-2019, Accepted: 12-06-2019

\begin{abstract}
Abstrak
Non-specific low back pain merupakan gejala nyeri pinggang bawah yang terjadi tanpa penyebab yang jelas, diagnosisnya berdasarkan eklusi dari patologi spesifik. Non-specific low back pain dapat mengakibatkan nyeri, spasme otot dan imbalance muscle, sehingga stabilitas otot perut dan punggung bawah mengalami penurunan, mobilitas lumbal terbatas, perubahan postur, dan mengakibatkan disabilitas pada pasien non-specific low back pain. Pemberian terapi latihan pada kasus non-specific low back pain sangat dianjurkan untuk peningkatan stabilitas dan koreksi postur pada tulang belakang, terapi latihan ini bisa berupa McKenzie exercise. Tujuan: penelitian ini untuk mengetahui pengaruh mckenzie excercise dalam penurunan disabilitas pasien non-specific low back pain. Metode: Jenis penelitian ini merupakan penelitian pre eksperimental dengan mengunakan rancangan one group pre and post test design. Penelitian dilaksanakan di Rumah Sakit Dr Soeradji Tirtonegoro Klaten. Subjek sebanyak 16 pasien yang memenuhi kriteria yang ditetapkan peneliti. Disabilitas diukur dengan oswestry disability index (ODI) sebelum dan sesudah pelatihan. Subjek diberikan mckenzie excercise dengan frekuensi 2 kali semingu selama 1 bulan. Hasil: Uji statistik didapatkan, terjadi penurunan skor ODI pada pemberian mckenzie excercise dengan nilai $p=0,000$. Kesimpulan: Hal ini menunjukan bahwa mckenzie excercise dapat menurunkan disabilitas pada pasien non-specific low back pain.
\end{abstract}

Kata kunci: McKenzie exercise, disabilitas, non-specific low back pain, oswestry disability index.

\footnotetext{
Abstract

Non-specific low back pain is the symptom of lower back pain that occurs without an obvious cause, the diagnosis is based on exclusion of specific pathology. Non-specific low back pain can result in pain, muscle spasm and muscle imbalance, it can decrease the stability of the abdominals and lower
}

back, limitation in lumbar mobility, changes posture, and it's couse make disability in patients with non-specific low back pain. Exercise therapy for non-specific low back pain is high recommend to increased stability and correct posture of the spine. The purpose of this study is to determine the effect of McKenzie Exercise to reduce patient disability in non-specific low back pain.

Method: This research applied pre experimental research method with one group Pre and Post Test Design. The research was conducted in Dr Soeradji Tirtonegoro hospital Klaten. There were 16 subjects taken for this research. Disability was measured by oswestry disability index (ODI) before and after treatment. Subject get Mckenzie exercise with the frequens are 2 times a weak in a month Result: Statistical test results obtained, have a decline ODI score at the McKenzie Exercise have done with a value of $p=0.000$. This means that Mckenzie excercise can reduce patients disability in non-specific low back pain.

Keywords: McKenzie exercises, disability, nonspecific low back pain, oswestry disability index.

\section{PENDAHULUAN}

Non-specific low back pain merupakan gejala nyeri pinggang bawah yang terjadi tanpa penyebab yang jelas. Non-specific low back pain diagnosa berdasarkan eklusi dari patologi spesifik dan ditemukannya nerve root pain (Balague, 2012). Non-specific low back pain ditemukan $83 \%$ dari total populasi yang ada sedangkan sisanya merupakan nerve root pain dan patologi spesifik. Non-specific low back pain dapat mengakibatkan nyeri, spasme otot dan imbalance muscle, sehingga stabilitas otot perut dan punggung bawah mengalami penurunan, mobilitas lumbal terbatas, perubahan postur, dan mengakibatkan disabilitas pada pasien non-specific low back pain. Pemberian terapi latihan pada kasus 
Non-specific low back pain sangat dianjurkan untuk peningkatan stabilitas dan koreksi postur pada tulang belakang, terapi latihan ini bisa berupa McKenzie exercise maupun core stability exercise. Tujuan penelitian ini untuk mengetahui core stability excercise lebih baik dibandingkan mckenzie excercise dalam penurunan disabilitas pasien non-specific low back pain.

Penyebab nyeri punggung bawah Nonspecific, yaitu yang tidak mengarah pada suatu proses patologi atau kelainan anatomik tertentu (misalnya strain otot, sprain ligamen, lumbago) dan nyeri punggung bawah spesifik, yaitu yang mengarah pada suatu proses patologis tertentu (misalnya infeksi, neoplasma, osteoporosis, rheumatoid arthritis, fraktur) (Koes, 2001).

Low back pain terjadi karena biomekanik vertebra lumbal akibat perubahan titik berat badan dengan kompensasi perubahan posisi tubuh dan akan menimbulkan nyeri. Ketegangan (strain) otot dan keregangan (sprain) ligamentum tulang belakang merupakan salah satu penyebab utama LBP. Sebagai contoh ketika seseorang duduk dengan tungkai atas berada pada posisi $90^{\circ}$, maka daerah lumbal belakang akan menjadi mendatar keluar yang dapat menimbulkan keadaan kifosis. Keadaan ini terjadi karena sendi panggul yang hanya berotasi sebesar $60^{\circ}$, mendesak pelvis untuk berotasi ke belakang sebesar $30^{\circ}$ untuk menyesuaikan tungkai atas yang berada pada posisi $90^{\circ}$. Kifosis lumbal selain menyebabkan peregangan ligamentum longitudinalis posterior, juga menyebabkan peningkatan tekanan pada diskus intervertebralis sehingga mengakibatkan peningkatan tegangan pada bagian dari annulus posterior dan penekanan pada nukleus pulposus dan menyebabkan terjadinya nyeri pinggang (Samara, 2004).

McKenzie exercise merupakan suatu teknik latihan dengan menggunakan gerakan badan terutama ke belakang/ekstensi, biasanya digunakan untuk penguatan dan peregangan otot-otot ekstensor dan fleksor sendi lumbosacralis dan dapat mengurangi nyeri (McKenzie, 2003). Latihan ini diciptakan oleh Robin Mc Kenzie. Prinsip latihan McKenzie adalah memperbaiki postur untuk mengurangi hiperlordosis lumbal. Sedangkan secara operasional pemberian latihan untuk penguatan otot punggung bawah ditujukan untuk otot-otot fleksor dan untuk peregangan ditujukan untuk otot-otot ektensor punggung (. Gerakan McKenzie Exercise di dalam penelitian ini terbagi menjadi 4 gerakan diantaranya: (1) Prone lying, (2) Prone on elbows, (3) Prone press up, (4) Standing backward bending. Gerakan-gerakan ini dilakukan selama 2-3 menit diulang sebanyak 3 kali tiap dengan frekuensi 2 kali seminggu dalam rentang waktu 4 minggu (Olson, 2015)

$$
\text { Disabilitas adalah beberapa }
$$

keterbatasan atau ketiadaan kemampuan akibat impairment untuk melakukan aktivitas secara benar-benar normal sebagai manusia (Purba, 2006) Dalam kasus ini disabilitas akan diukur menggunakan Oswestry Disability Index yang merupakan suatu index atau kuesioner untuk mengukur disabilitas seseorang dalam aktivitas sehari-hari yang berkaitan dengan timbulnya nyeri pada punggung bawah. Quisioner ini terdiri 10 sesi yaitu : intensitas nyeri, perawatan diri, aktivitas mengangkat, aktivitas berjalan, duduk, berdiri, tidur, aktivitas seksual, kehidupan sosial dan pada saat bepergian (Davidson, 2002)

\section{METODE}

Penelitian ini dilakukan di RSUP Penelitian ini dilakukan di RSUP Soeradji Tirtonegoro Klaten selama 2 bulan pada bulan Maret sampai dengan April 2017.

Jenis penelitian adalah penelitian pre eksperimental dengan rancangan penelitian yang digunakan adalah one group pre and post test design.

Penelitian ini dilakukan untuk Untuk membuktikan Apakah ada pengaruh McKenzie excercise dalam menurunkan disabilitas pasien non-specific low back pain.

Populasi dalam penelitian ini adalah Pasien Non-specific Low Back Pain di RSUP Soeradji Tirtonegoro Klaten. Subjek penelitian yang diambil adalah 16 orang dan akan diberi perlakuan berupa McKenzie Exercise dengan frekuensi 2 kali perminggu selama 4 minggu,

Sebelum diberikan intervensi dilakukan terlebih dahulu pengambilan sampel berdasarkan seleksi atau penilaian yang memenuhi kriteria dari non-specific low back pain. Sampel diambil dari populasi disesuakian dengan kriteria inklusi, kriteria eksklusi dan kriteria pengguguran.

Data diolah dengan menggunakan perangkat lunak komputer dengan SPSS, adapun analisis data yang dilakukan antara lain: 
1. Statistik deskriptif untuk menganilisis usia, jenis kelamin, dan indeks masa tubuh (IMT).

2. Uji normalitas data dengan Saphiro Wilk Test, untuk mengetahui data berdistribusi normal atau tidak. Apabila Nilai $p$ lebih besar dari 0,05 ( $p>0,05)$.

3. Uji Hasil uji beda nilai ODI perkelompok Hasil uji beda digunakan untuk mengetahui dan membandingkan rerata nilai ODI sebelum dan sesudah latihan McKenzie exercise, yaitu hasil analisis kemaknaan menggunakan uji t-paired (berpasangan) untuk intra kelompok. Nilai $\mathrm{p}<0,05$ yang artinya bahwa terdapat peningkatan yang bermakna pada nilai ODI.

\section{HASIL}

Populasi dalam penelitian ini adalah semua pasien non-specific low back pain yang telah dilakukan pemeriksaan. Pengambilan sampel diambil secara random dan sesuai dengan kriteria yang ditetapkan hingga jumlah memenuhi yang ditargetkan.

Subjek penelitian berjumlah 16 orang dan mendapatkan perlakuan berupa McKenzie Exercise dengan frekuensi 2 kali perminggu selama 4 minggu, pengambilan sampel dilakukan dari bulan Maret 2017 sampai April 2017. Penilaian disabilitas dengan oswestry disability index (ODI) dilakukan sebelum dan sesudah perlakuan.

Berdasarkan uji karakteristik didapatkan umur terbanyak berada pada golongan umur 55-59, dengan nilai mean $54,81 \pm 4,09$. Jenis kelamin memiliki distribusi jumlah yang seimbang antara laki-laki dan perempuan. Pembagian IMT didapatkan hasil terbanyak ada di golongan obesitas 1 dengan rerata nilai IMT 25,52 $\pm 2,766$.

Tabel 1

Hasil uji normalitas dan homogenitas

\begin{tabular}{lc}
\hline \multirow{2}{*}{$\begin{array}{c}\text { Skor ODI } \\
(\%)\end{array}$} & $\begin{array}{c}\text { Nilai p Saphiro Wilk } \\
\text { test }\end{array}$ \\
\cline { 2 - 2 } & Kel 2 \\
\hline Sebelum & 0,291 \\
Sesudah & 0,238 \\
\hline \multicolumn{2}{c}{ Berdasarkan hasil uji normalitas } \\
(Saphiro wilk test) data penurunan skor ODI \\
sebelum dan sesudah pelatihan baik sebelum \\
pelatihan maupun sesudah pelatihan
\end{tabular}

didapatkan nilai $\mathrm{p}>0,05$ sehingga dinyatakan data berdistribusi normal.

Tabel 2

Uji hipotesis penurunan skor ODI

\begin{tabular}{lccc}
\hline \multirow{4}{*}{ Perlakuan } & $\begin{array}{c}\text { Pre } \\
\text { Mean } \pm\end{array}$ & $\begin{array}{c}\text { Post } \\
\text { Mean } \pm\end{array}$ & $\mathrm{p}$ \\
& SD $(\%)$ & SD $(\%)$ & \\
\hline McKenzie & $36,63 \pm$ & $32,50 \pm$ & 0,000 \\
& 10,996 & 11,673 & \\
\hline
\end{tabular}

Tabel 2 memperlihatkan penurunan skor ODI antara sebelum dan sesudah pelatihan yang dianalisis dengan uji komparasi parametric paired sample $t$ test dengan nilai $\mathrm{p}=0,000$. Hasil nilai tersebut menyatakan secara signifikan McKenzie exercise dapat menurunkan disabilitas pasien non-specific low back pain.

\section{PEMBAHASAN}

Gangguan yang dapat terjadi pada low back pain yaitu nyeri pada daerah punggung bawah, spasme pada otot-otot punggung bawah, sehingga potensial terjadi ketidakseimbangan antara otot abdominal dan paravertebrae yang dapat menimbulkan keterbatasan saat bergerak. Hal ini akan mengakibatkan penurunan mobilitas lumbal akibat adanya nyeri, spasme, ketidakseimbangan otot abdominal dan paravertebrae, sehingga aktivitas fungsional terganggu (Hayden, 2005).

Hasil penurunan disabilitas pada pasien non-specific low back pain bisa terjadi karena proses sentralisasi diskus intervertebralis dengan metode McKenzie Exercise. Pada posisi ekstensi yang dipertahankan dalam selama beberapa detik akan diperoleh peregangan pada jaringan lunak bagian anterior yaitu ligament anterior sehingga akan mengembalikan posisi spine pada posisi ekstensi/lordosis. Hal ini merupakan suatu counter posisi yang menimbulkan dorongan diskus ke anterior. Pada otot yang spasme akan terjadi pelemasan (relaksasi) oleh peregangan yang intermiten dan kontinyu terhadap otot antagonis. Pelemasan ini terjadi karena adanya peregangan yang akan merangsang golgi tendon sehingga terjadi reflek relaksasi otot yang bersangkutan. Peregangan intermiten akan memperbaiki mikro sirkulasi oleh mekanisme pumping action sehingga mengurangi iritasi pada saraf afferen yang menimbulkan reflek peningkatan tonus otot. 
Selanjutnya terjadi penekanan diskus ke sisi anterior, sehingga akan didapat gaya tangensial yang mendorong nukleus ke ventral. Akibat adanya gerak dinamis ekstensi yang dilakukan berulang dapat meningkatkan cairan diskus dan korpus yang kemudian akan menurunkan viskositas nucleus pulposus dan dapat mengurangi iritasi terhadap jaringan sekitarnya. Kondisi seperti ini membuat nyeri berkurang dan postur menjadi lebih baik, sehingga disabilitas dapat diturunkan (McKenzie, 2003).

\section{KESIMPULAN}

Hasil penelitian ini menyimpulkan bahwa McKenzie excercise dapat menurunkan disabilitas pasien non-specific low back pain.

\section{DAFTAR PUSTAKA}

Balagué, F., Mannion, A. F., Pellisé, F., \& Cedraschi, C. (2012). Non-specific low back pain. The Lancet, 379(9814), 482-491.

Koes, B. W., van Tulder, M. W., Ostelo, R., Burton, A. K., \& Waddell, G. (2001). Clinical guidelines for the management of low back pain in primary care: an international comparison. Spine, 26(22), 2504-2513.

Samara, D. (2004). Lama dan sikap duduk sebagai faktor risiko terjadinya nyeri pinggang bawah. Universa Medicina, 24(2), 63-71.

McKenzie, R., \& May, S. (2003). The lumbar spine: mechanical diagnosis and therapy. Orthopedic Physical Therapy. 2(1), 12-21.

Olson, K. A. (2015). Manual physical therapy of the spine. Elsevier Health Sciences.

Purba, J. S., \& Rumawas, A. M. (2006). Nyeri punggung bawah studi Epidemiologi, patofisiologi dan penanggulaan. Berkala Neuro Sains, 7

Davidson, M., \& Keating, J. L. (2002). A comparison of five low back disability questionnaires: reliability and responsiveness. Physical therapy, 82(1), 824.

Hayden, J., Van Tulder, M. W., Malmivaara, A., \& Koes, B. W. (2005). Exercise therapy for treatment of non specific low back pain. The Cochrane Library. 